\title{
A subgingivális air-abrazív terápia hozzáadott hatása a krónikus parodontitis nem-sebészi kezelésében
}

\author{
Randomizált, kontrollált pilot study
}

DR. KOMLÓSI LAURA*, DR. VÁLYI PÉTER**

\begin{abstract}
A parodontitis kezelésében a mai napig elengedhetetlen a subgingivális debrimentálás, amelynek hatékonyságát többféle kiegészítő terápiával próbálják fokozni, így az általunk jelen klinikai kísérletben használt subgingivális air-abrazív készülék alkalmazásával is.

A kutatás első fázisában 8 páciens klinikai paramétereinek változását tudtuk értékelni „split-mouth” vizsgálatunkban, a tesztoldalon a hagyományos eszközökkel végzett subgingivális debrimentálást subgingivális air-abrazív kezeléssel egészítettük ki glycin por felhasználásával.

Egy hónappal a beavatkozás után statisztikailag értékelhető különbséget nem találtunk a teszt- és a kontrolloldal között, a klinikai paraméterek mindkét oldalon szignifikáns javulást mutattak. A további szignifikáns javulás a tesztoldalon volt észlelhető a terápiát követő 3 hónap után elvégzett mérések szerint, és különösen a nehezen hozzáférhető helyeken (mély tasak, többgyökerű fogak) volt kedvezőbb az air-abrazív módszer kiegészítő hatása.

Jelen, kis mintán végzett vizsgálatunkból azt a megállapítást tehetjük, hogy az air-abrazív módszer kiegészítő hatása a subgingivális debrimentálás hosszabb távú sikeréhez és a nehezebben hozzáférhető területek eredményesebb kezeléséhez vezethet.
\end{abstract}

Kulcsszavak: chronicus parodontitis, subgingivális instrumentálás, subgingivális air-abrazív terápia

\section{Bevezetés}

A parodontitis egy multifaktoriális gyulladásos kórkép, amely a fog támasztószöveteinek irreverzibilis destrukcióját okozza. A kórkép összefügg a fog felszínén képződő biofilm diszbiózisával: a patogén mikroorganizmusok túlzott elszaporodásával. Ez egyben komoly népegészségügyi problémát jelent, mivel előfordulása gyakori, hatással van a szisztémás egészségi állapotra és a következményeként kialakuló fogelvesztés, esztétikai és funkcionális eltérések az életminőségre gyakorolt negatív hatáson kívül komoly költségráfordítást igényelnek ellátásuk során [1].

A parodontális terápia sikere rövid- és hosszútávon egyaránt függ a nem-sebészi mechanikus parodontális kezeléstől, azaz a subgingivális biofilm struktúrájának roncsolásától, a baktériumok minél nagyobb tömegének eltávolításától [2,3]. A subgingivális terület gépi és kézi eszközökkel történő tisztítása a mai napig a parodontális kezelések „gold standardja”, jelentősen javítja a klinikai paramétereket: a vérzési indexet $45 \%$ kal csökkenti, 1,29-2,2 mm-es tasakredukciót és 0,5$2 \mathrm{~mm}$-es klinikai tapadásnyereséget eredményez [4].

Számos tényező befolyásolja a nem-sebészi terápia sikerességét. Az eltávolított depozitumok mennyiségét a kezdeti tasakmélység, a fogak anatómiai viszonyai, a felszínek komplexitása és nem utolsó sorban a kezelést végző személy gyakorlati tapasztalatától függ. Ezek a tényezők jelentős befolyást gyakorolnak a terápia várható eredményére. A kiindulási tasakmélységek alapján a 4-5 mm-es tasak kezelése során legfeljebb $29 \%$ visszamaradt bakteriális felrakódást találtak, ez a $6 \mathrm{~mm}$-nél mélyebb tasakokban már a $44 \%$-ot is elérheti [5]. A bakteriális biofilm minél nagyobb tömegének eltávolítása többféle úton javítja a terápia sikerességét: a baktériumok eltávolításával a visszafertőződés esélyét csökkentjük, a klinikai paraméterek javulásával a környezeti tényezők is kedvezőtlenebbek lesznek a parodontopatogén mikroorganizmusok túléléséhez, illetve a biofilm struktúrájának roncsolásával a szisztémás és lokális kemoterápia is hatásosabbá válik [6].

A subgingivális instrumentálás hatásosságát olyan eszközök alkalmazásával lehet fokozni, amelyek hozzáférést biztosítanak a subgingivális terület keményés lágyszöveti ökológiai réseihez, a nehezen megközelíthető anatómiai helyekhez, nem függ a felhasználó ügyességétől, illetve kiküszöböli a hagyományos kézi és gépi eszközök által keltett diszkomfortérzést $[7,8]$.

A levegőabráziós készüléket a fogászatban már 1945 óta alkalmazzák. Aluminium oxid port használva, kavi- 
tásalakítás és az ínyszél feletti fogfelszínek tisztításának céljára vezették be [9]. A supragingivális depozitok eltávolítására már az 1980-as évektől biztonságosan használják a natrium bikarbonát port anélkül, hogy különös felszínkárosító hatása lenne, viszont a gyökércementen, illetve a lágyrészeken komoly károsodást képes előidézni. Sebészeti alkalmazása kontraindikált, elsősorban az emphysema veszélye miatt, valamint a szövetekbe, vagy a keringésbe jutva esetlegesen káros hatást fejthet ki [8].

A gyökércement és a lágyszövetek biztonságos levegőabráziós kezelésére a glycinport kezdték használni [10]. A biofilm eltávolító képessége mellett bebizonyosodott, hogy biztonságosan lehet alkalmazni, és a páciens számára a kezelés nem jár kellemetlenségekkel [11]. A módszer hatásosságát leginkább a szupportív terápia során figyelték meg $[11,12,13,14,15]$. In vivo vizsgálatunk célja az volt, hogy krónikus fogágygyulladásban szenvedő, kezeletlen páciensek subgingivális terápiája során megvizsgáljuk, hogy a glycinporral végzett subgingivális air-abrazív kiegészítő kezelés javítja-e a konvencionális terápia eredményességét.

\section{Betegek és módszer}

A résztvevő személyek kiválasztása a Szegedi Tudományegyetem Fogorvostudományi Karának Parodontológiai Tanszékén kezelésre jelentkező/beutalt páciensek közül történt. A 2017 júliusa és 2018 márciusa közötti időszakban, a beválasztási kritériumokat 15 páciens teljesítette, akik közül, különböző okok miatt, kizárásra került 7 páciens (1. ábra). Vizsgálatunkban nyolc (öt férfi és három nő) 40 és 62 év közötti krónikus parodontitisben szenvedő páciens vett részt. Életkoruk átlaga 48,9 év volt.

A klinikai vizsgálatban való részvétel feltétele volt a betöltött 18. életév, valamint az első parodontális státuszfelvétel során kvadránsonként minimum kettő 4-mmes vagy annál mélyebb szondázási mélységet mutató tasak jelenléte, és az, hogy az érintett fogak prognózisa nem reménytelen.

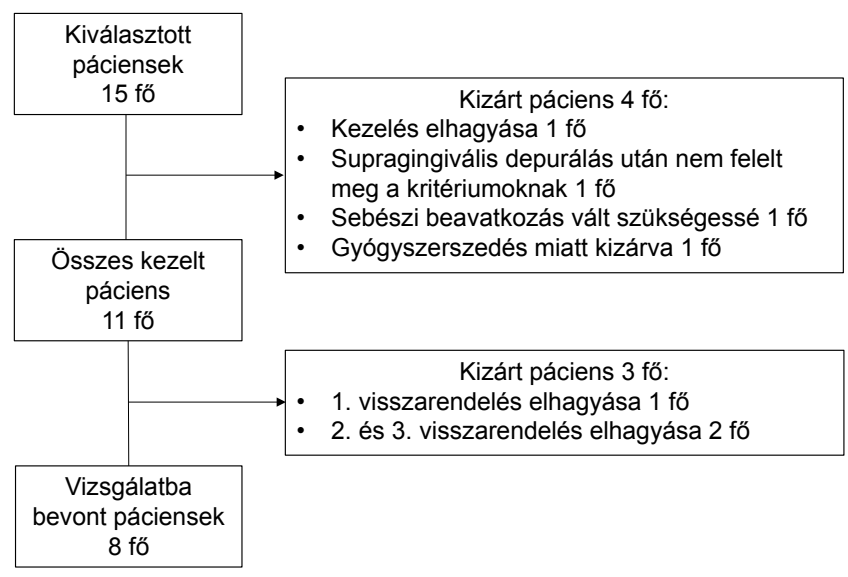

1. ábra: A vizsgálatba bevont személyek
A vizsgálatban kizáró tényezők az alábbiak voltak:

- terhes/szoptató nők;

- aktívan dohányzó páciensek;

- akut, fertőző szájüregi elváltozással rendelkezők;

- olyanok, akik a kezelés előtti 6 hónapon belül szisztémás antibiotikum terápiában részesültek; vagy antibiotikum profilaxisra szoruló betegek;

- szisztémás betegségben szenvedők (krónikus bronchitis, asthma bronchiale, diabetes mellitus, hematológiai betegségek, fertőző betegségek, daganatos betegségek, csontmetabolizmus zavarok, sebgyógyulást befolyásoló betegségek).

- egyéni szájhigiénia fenntartását akadályozó mentális/ fizikális károsodások;

- anti-inflammatorikus terápia;

- továbbá minden olyan szisztémás betegség, állapot vagy gyógyszerszedés, amely a kezelés eredményes-ségét befolyásolhatja, illetve a kezelést kontraindikálja.

Az első találkozás alkalmával általános és fogászati anamnézisfelvételt, valamint extra- és intraorális vizsgálatot követően, parodontális státuszfelvétel, supragingivális plakk- és fogkő-eltávolítás, és egyéni szájhigiénés tanácsadás történt. Mérlegeltük, hogy voltak-e olyan reménytelen prognózisú fogak, amelyek eltávolítása indikált, olyan plakkretenciós tényezők, amelyek korrekcióra szorultak, és olyan, legalább kettes fokú mobilis fogak, amelyeknek sínezéssel történő rögzítése volt szükséges.

A parodontális státuszfelvétel CP 15-ös típusú parodontális szondával (HU-FRIEDY, Chicago, USA) történt. Az általunk vizsgált paraméterek az alábbiak voltak:

- Silness-Löe Plaque Index (PI): 4 felszínen (mezialis, vestibularis, distalis, oralis)

- Löe-Silness Gingivalis Index (GI): 6 felszínen (meziovestibularis, centrovestibularis, distovestibularis, meziooralis, centrooralis, distooralis)

- Szondázási mélység (PPD) 6 felszínen (meziovestibularis, centrovestibularis, distovestibularis, meziooralis, centrooralis, distooralis)

- Ínyrecesszió (REC): 6 felszínen (meziovestibularis, centrovestibularis, distovestibularis, meziooralis, centrooralis, distooralis)

- Klinikai tapadásveszteség (CAL)

- Fogmobilitás (Nield-Gehrig and Houseman, 1996)

- Furkációérintettség (Hamp et al, 1975)

Az instruálás, motiválás egyénre szabottan történt: felhívtuk a betegek figyelmét a megfelelően végzett otthoni szájápolási szokások fontosságára, külön hangsúlyt fektetve az approximális területek tisztítására, tájékoztattuk őket a számukra legmegfelelőbb eszközök megválasztásáról, és mulázs segítségével demonstráltuk ezek helyes használatát.

A következő ülésben 4 mm-es, illetve annál mélyebb tasakokat helyi érzéstelenítésben kezeltük, az irodalomból jól ismert módszer szerint, ugyanazon páciens- 
nél teszt és kontroll területet is kialakítva. A száj egyik oldalán lévő kvadránsokat randomizációs módszerrel a teszt, a másik oldalt a kontroll csoportba soroltuk. A kontroll oldalon először Woodpecker UDS-N2 típusú ultrahangos depurátorral (MEDIDENT, Cobham, United Kingdom), majd 5/6, 7/8, 11/12, 13/14-es LMSyntette Gracey küretekkel (LM-DENTAL, Parainen, Finland) végeztünk subgingivalis instrumentálást, amelyet air-abrazív technikával egészítettünk ki a vizsgálati oldal esetében. Itt a glicin alapú port (NSK PerioMate Powder, NAKANISHI, Shimohinata, Japan) nagynyomású víz-levegő-permet segítségével, tasakonként 5 másodpercen keresztül NSK PerioMate kézidarab segítségével (NAKANISHI, Shimohinata, Japan) juttattuk a foggyökér felszínére az ínyszél alatti területen. A beavatkozást követően a tasakokat fiziológiás sóoldattal alaposan átöblítettük. Teljes száj dezinfekciós kezelést végeztünk 24 órán belül, a kezeletlen tasakokból történő reinfekció elkerülése érdekében [16].

A terápiát követően 1, 3 és 6 hónap elteltével újraértékelést végeztünk, ahol a fenti parodontális paramétereket rögzítettük. Szükség esetén ismételten instruáltuk, motiváltuk a pácienseket. A féléves kontrollt követően a 4 mm-nél mélyebb tasakok kezelését ismételt nem-sebészi, illetve, amennyiben szükséges volt, sebészi terápiával folytatjuk.

Az adatok elemzését nem-paraméteres eljárásokkal (csoporton belül Wilcoxon és csoportok között Mann-Whitney U teszt) Statistica 13.0 szoftverrel végeztük.

\section{Eredmények}

A páciensek kezelése során váratlan esemény, szövődmény nem fordult elő. Diszkomfort érzésről nem számoltak be a páciensek, hámfosztott terület kialakulása vagy indokolatlan vérzés nem fordult elő.

A klinikai paramétereket táblázatokban, illetve - a plakkindex esetében - grafikonon tüntettük fel. Az eredmények alapján megállapítható, hogy a nem-sebészi parodontális terápia minden klinikai paraméter esetében statisztikailag bizonyítható javulást mutat. Az air-abrazív terápia előnye a nehezen hozzáférhető helyeken, illetve a hosszabb hatástartamban mutatkozik meg. Az összes kezelt tasakot értékelő táblázatban (1. táblázat) a kontroll oldalon az 1. és 3. hónap után végzett ellenőrzések során mért értékek, bár javulást mutatnak, de nem szignifikáns a különbség, szemben a teszt oldallal, ahol a pozitív változás statisztikailag is kimutatható. A 2. táblázatban a kezelt fogaknál, a kiindulási szondázási mélység alapján, a kezelést követő tasakmélység értékek megoszlását mutatjuk be. Itt is látható, hogy az air-abrazív módszerrel kezelt esetekben az 1. hónap után is javuló értékeket kapunk, illetve a megmaradó, mély tasakok száma is jóval kevesebb.

A 3., 4. és 5. táblázatban különböző csoportokban vizsgáltuk az eredmények alakulását (szondázási mély-

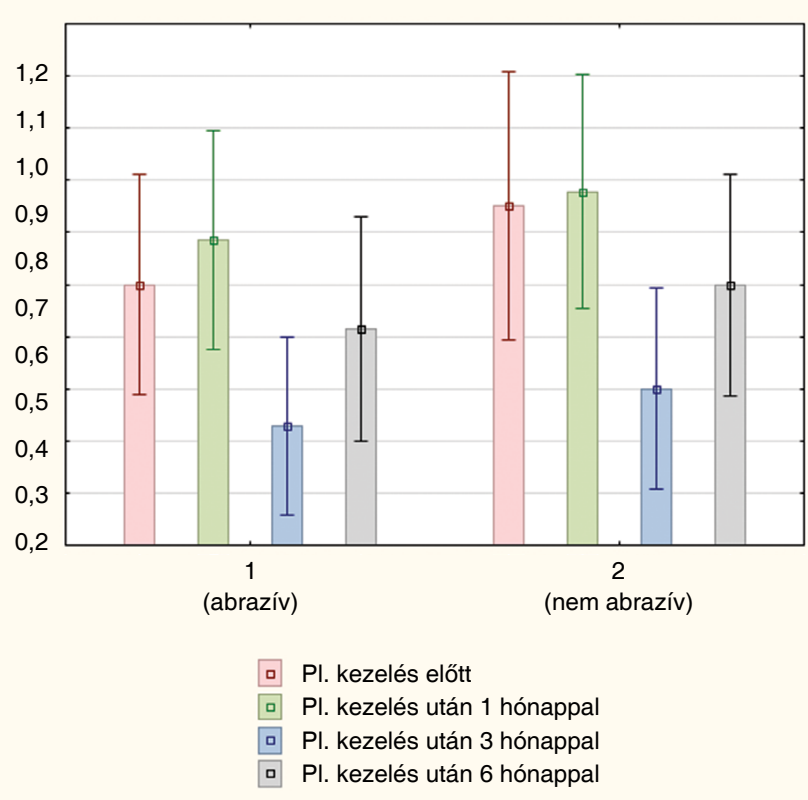

2. ábra: A plakk index értékek alakulása a vizsgálati és kontroll oldalon

ség, klinikai tapadásnyereség, gingivális index) az alapján, hogy van-e különbség a vizsgált módszer hatásosságában annak alapján, hogy könnyebben (egygyökerü fogak, közepesen mély szondázási mélység) vagy nehezebben (többgyökerü fogak, mély tasakok) hozzáférhető helyeken alkalmazzuk. A kapott eredmények azt mutatják, hogy a tesztoldalon a hosszabb távú hatás elsősorban a könnyebben hozzáférhető helyeken jelentkezik. A mélyebb tasakoknál és a többgyökerű fogaknál pedig a legtöbb paraméter esetében erősebb hatást tapasztalunk a tesztoldalon, de ez a különbség nem szignifikáns.

Azt mindenképpen meg kell jegyeznünk, hogy a plakkindex értékek alakulása azt mutatja, hogy a terápiát követő első hónapban a páciensek szájhigiéniája romlik, viszont az ismételt motiválás után jelentősen jobb értékeket mértünk a kezelés után 3 hónappal, és ez a hatás kisebb mértékben még a féléves kontrolloknál is megmaradt (2. ábra).

\section{Megbeszélés}

A parodontitis terápiájának mai napig fontos része az oki kezelés, a supra-, de főleg subgingivális fogfelszínen felhalmozódó biofilm eltávolítása. Ahhoz, hogy a gyulladást megfelelően kontrolláljuk, és a további progressziót elkerüljük, a felhalmozódott mikrobiális felrakódás döntő hányadának eltávolítása szükséges mind a fogfelszínről, mind a subgingivalis, illetve intraorális ökológiai résekből. A konvencionális, kézi és gépi eszközökkel végzett mechanoterápia csak korlátozott mértékben tud a fenti követelményeknek eleget tenni, ezért 
A klinikai paraméterek (szondázási mélység, tapadási nívó, gingivális index) alakulása a vizsgálati és tesztoldalon

\begin{tabular}{|l|c|c|c|c|c|c|}
\hline & \multicolumn{3}{|c|}{ Air-abrazív } & \multicolumn{3}{c|}{ Kontroll } \\
\cline { 2 - 7 } & $\begin{array}{c}\text { Szondázási } \\
\text { mélység } \\
\left(\begin{array}{c}\text { átlag } \pm \text { SD) } \\
(\mathrm{mm})\end{array}\right.\end{array}$ & $\begin{array}{c}\text { Klinikai } \\
\text { tapadási nívó } \\
(\text { átlag } \pm \text { SD) } \\
(\mathrm{mm})\end{array}$ & $\begin{array}{c}\text { Gingivális } \\
\text { index } \\
(\text { átlag } \pm \text { SD) } \\
(\mathrm{mm})\end{array}$ & $\begin{array}{c}\text { Szondázási } \\
\text { mélység } \\
\text { (átlag } \pm \text { SD) } \\
(\mathrm{mm})\end{array}$ & $\begin{array}{c}\text { Klinikai } \\
\text { tapadási nívó } \\
(\text { átlag } \pm \text { SD) } \\
(\mathrm{mm})\end{array}$ & $\begin{array}{c}\text { Gingivális } \\
\text { index } \\
\text { (átlag } \pm \text { SD) } \\
(\mathrm{mm})\end{array}$ \\
\hline Kezdeti érték & $5,61 \pm 1,33$ & $6,04 \pm 1,56$ & $1,99 \pm 0,12$ & $5,77 \pm 1,85$ & $6,47 \pm 2,31$ & $1,97 \pm 0,16$ \\
\hline 1 hónap & $3,79 \pm 1,41$ & $4,33 \pm 1,61$ & $1,84 \pm 0,37$ & $4,05 \pm 2,01$ & $4,74 \pm 2,37$ & $1,81 \pm 0,39$ \\
\hline 3 hónap & $3,39 \pm 1,57$ & $4,01 \pm 1,66$ & $1,74 \pm 0,44$ & $3,78 \pm 2,03$ & $4,43 \pm 2,26$ & $1,76 \pm 0,43$ \\
\hline 6 hónap & $4,00 \pm 1,47$ & $4,74 \pm 1,65$ & $1,87 \pm 0,34$ & $4,00 \pm 1,79$ & $4,81 \pm 2,02$ & $1,86 \pm 0,35$ \\
\hline
\end{tabular}

A legmélyebb szondázási mélységértékek megoszlása

2. táblázat a kezelt tasakok esetében

\begin{tabular}{|l|c|c|c|c|c|c|}
\hline & \multicolumn{3}{|c|}{ Air-abrazív } & \multicolumn{3}{c|}{ Kontroll } \\
\cline { 2 - 8 } & $\mathbf{0 - 3} \mathbf{~ m m}$ & $\mathbf{4 - 6} \mathbf{~ m m}$ & $\mathbf{6} \mathbf{~ m m <}$ & $\mathbf{0 - 3} \mathbf{~ m m}$ & $\mathbf{4 - 6} \mathbf{~ m m}$ & $\mathbf{6 ~} \mathbf{~ m}<$ \\
\hline Kezdeti érték & - & 58 & 12 & - & 59 & 15 \\
\hline 1 hónap & 27 & 39 & 4 & 37 & 29 & 8 \\
\hline 3 hónap & 36 & 31 & 3 & 34 & 33 & 7 \\
\hline 6 hónap & 31 & 37 & 2 & 32 & 35 & 7 \\
\hline
\end{tabular}

A szondázási mélységértékek (átlag $\pm S D$ ) alakulása

a könnyebben (egygyökerü fogak, közepesen mély tasak)

és nehezebben (többgyökerü fogak, mély tasak) hozzáférhető területeken

\begin{tabular}{|c|c|c|c|c|c|c|c|c|}
\hline & \multicolumn{4}{|c|}{ Air abrazív } & \multicolumn{4}{|c|}{ Kontroll } \\
\hline & $\begin{array}{l}\text { Egy- } \\
\text { gyökerü } \\
\text { fogak } \\
(\mathrm{mm})\end{array}$ & $\begin{array}{c}\text { Több- } \\
\text { gyökerü } \\
\text { fogak } \\
(\mathrm{mm})\end{array}$ & \begin{tabular}{|c|} 
4-6 mm \\
kiindulási \\
szondázási \\
mélység \\
$(\mathrm{mm})$
\end{tabular} & $\begin{array}{c}6 \text { mm } \\
\text { kiindulási } \\
\text { szondázási } \\
\text { mélység } \\
(\mathrm{mm})\end{array}$ & $\begin{array}{l}\text { Egy- } \\
\text { gyökerü } \\
\text { fogak } \\
(\mathrm{mm})\end{array}$ & $\begin{array}{l}\text { Több- } \\
\text { gyökerú } \\
\text { fogak } \\
(\mathrm{mm})\end{array}$ & \begin{tabular}{|c|} 
4-6 mm \\
kiindulási \\
szondázási \\
mélység \\
$(\mathrm{mm})$
\end{tabular} & $\begin{array}{c}\text { > } 6 \mathrm{~mm} \\
\text { kiindulási } \\
\text { szondázási } \\
\text { mélység } \\
(\mathrm{mm})\end{array}$ \\
\hline Kezdeti érték & $5,40 \pm 0,93$ & $5,96 \pm 1,76$ & $5,07 \pm 0,60$ & $7,60 \pm 1,40$ & $5,53 \pm 1,52$ & $6,50 \pm 2,13$ & $4,95 \pm 0,75$ & $9,00 \pm 1,25$ \\
\hline 1 hónap & $3,37 \pm 1,09$ & $4,44 \pm 1,63$ & $3,31 \pm 0,92$ & $5,53 \pm 1,55$ & $3,41 \pm 1,44$ & $5,11 \pm 2,38$ & $3,32 \pm 1,11$ & $6,93 \pm 2,22$ \\
\hline 3 hónap & $3,00 \pm 1,33$ & $4,00 \pm 1,75$ & $3,00 \pm 1,25$ & $4,80 \pm 1,86$ & $3,20 \pm 1,49$ & $4,75 \pm 2,43$ & $3,14 \pm 1,21$ & $6,33 \pm 2,58$ \\
\hline 6 hónap & $3,65 \pm 1,38$ & $4,56 \pm 1,48$ & $3,69 \pm 1,29$ & $5,13 \pm 1,60$ & $3,41 \pm 1,65$ & $5,00 \pm 1,57$ & $3,47 \pm 1,22$ & $6,21 \pm 2,12$ \\
\hline
\end{tabular}

A klinikai tapadási nívó értékek (átlag $\pm S D$ ) alakulása

a könnyebben (egygyökerü fogak, közepesen mély tasak)

és nehezebben (többgyökerü fogak, mély tasak) hozzáférhető területeken

\begin{tabular}{|l|c|c|c|c|c|c|c|c|}
\hline & \multicolumn{4}{|c|}{ Air abrazív } & \multicolumn{4}{c|}{ Kontroll } \\
\cline { 2 - 9 } & $\begin{array}{c}\text { Egy- } \\
\text { gyökerü } \\
\text { fogak } \\
(\mathrm{mm})\end{array}$ & $\begin{array}{c}\text { Több- } \\
\text { gyökerü } \\
\text { fogak } \\
(\mathrm{mm})\end{array}$ & $\begin{array}{c}\mathbf{4 - 6} \mathbf{~ m m} \\
\text { kiindulási } \\
\text { szondázási } \\
\text { mélység } \\
(\mathrm{mm})\end{array}$ & $\begin{array}{c}\mathbf{>} \mathbf{~ m m} \\
\text { kiindulási } \\
\text { szondázási } \\
\text { mélység } \\
(\mathrm{mm})\end{array}$ & $\begin{array}{c}\text { Egy- } \\
\text { gyökerü } \\
\text { fogak } \\
(\mathrm{mm})\end{array}$ & $\begin{array}{c}\text { Több- } \\
\text { gyökerú } \\
\text { fogak } \\
(\mathrm{mm})\end{array}$ & $\begin{array}{c}\mathbf{4 - 6} \mathbf{~ m m} \\
\text { kiindulási } \\
\text { szondázási } \\
\text { mélység } \\
(\mathrm{mm})\end{array}$ & $\begin{array}{c}\mathbf{>} \mathbf{~ m m} \\
\text { kiindulási } \\
\text { szondázási } \\
\text { mélység } \\
(\mathrm{mm})\end{array}$ \\
\hline Kezdeti érték & $5,72 \pm 1,30$ & $6,56 \pm 1,80$ & $5,51 \pm 1,10$ & $8,00 \pm 1,41$ & $6,04 \pm 1,99$ & $7,18 \pm 2,64$ & $5,68 \pm 1,59$ & $9,60 \pm 2,03$ \\
\hline 1 hónap & $3,81 \pm 1,31$ & $5,15 \pm 1,73$ & $3,87 \pm 1,32$ & $6,00 \pm 1,51$ & $4,07 \pm 1,70$ & $5,86 \pm 2,88$ & $4,03 \pm 1,51$ & $7,53 \pm 3,07$ \\
\hline 3 hónap & $3,47 \pm 1,35$ & $4,89 \pm 1,76$ & $3,73 \pm 1,52$ & $5,07 \pm 1,79$ & $3,85 \pm 1,51$ & $5,39 \pm 2,92$ & $3,81 \pm 1,37$ & $6,87 \pm 3,31$ \\
\hline 6 hónap & $4,33 \pm 1,49$ & $5,44 \pm 1,67$ & $4,42 \pm 1,56$ & $5,93 \pm 1,44$ & $4,26 \pm 1,72$ & $5,74 \pm 2,18$ & $4,22 \pm 1,40$ & $7,29 \pm 2,37$ \\
\hline
\end{tabular}


A gingivális index értékek (átlag $\pm S D$ ) alakulása

a könnyebben (egygyökerü fogak, közepesen mély tasak)

és nehezebben (többgyökerü fogak, mély tasak) hozzáférhető területeken

\begin{tabular}{|c|c|c|c|c|c|c|c|c|}
\hline & \multicolumn{4}{|c|}{ Air abrazív } & \multicolumn{4}{|c|}{ Kontroll } \\
\hline & $\begin{array}{l}\text { Egy- } \\
\text { gyökerü } \\
\text { fogak } \\
(\mathrm{mm})\end{array}$ & $\begin{array}{c}\text { Több- } \\
\text { gyökerü } \\
\text { fogak } \\
(\mathrm{mm})\end{array}$ & $\begin{array}{c}\text { 4-6 mm } \\
\text { kiindulási } \\
\text { szondázási } \\
\text { mélység } \\
(\mathrm{mm})\end{array}$ & $\begin{array}{c}>6 \mathrm{~mm} \\
\text { kiindulási } \\
\text { szondázási } \\
\text { mélység } \\
(\mathrm{mm})\end{array}$ & $\begin{array}{l}\text { Egy- } \\
\text { gyökerü } \\
\text { fogak } \\
(\mathrm{mm})\end{array}$ & $\begin{array}{c}\text { Több- } \\
\text { gyökerü } \\
\text { fogak } \\
(\mathrm{mm})\end{array}$ & $\begin{array}{c}\text { 4-6 mm } \\
\text { kiindulási } \\
\text { szondázási } \\
\text { mélység } \\
(\mathrm{mm})\end{array}$ & $\begin{array}{c}>6 \text { mm } \\
\text { kiindulási } \\
\text { szondázási } \\
\text { mélység } \\
(\mathrm{mm})\end{array}$ \\
\hline Kezdeti érték & $2,00 \pm 0,00$ & $1,96 \pm 0,19$ & $1,98 \pm 0,13$ & $2,00 \pm 0,00$ & $1,98 \pm 0,15$ & $1,96 \pm 0,19$ & $1,97 \pm 0,18$ & $2,00 \pm 0,00$ \\
\hline 1 hónap & $1,77 \pm 0,43$ & $1,96 \pm 0,19$ & $1,84 \pm 0,37$ & $1,87 \pm 0,35$ & $1,76 \pm 0,43$ & $1,89 \pm 0,31$ & $1,76 \pm 0,43$ & $2,00 \pm 0,00$ \\
\hline 3 hónap & $1,74 \pm 0,44$ & $1,74 \pm 0,45$ & $1,71 \pm 0,46$ & $1,87 \pm 0,35$ & $1,70 \pm 0,47$ & $1,86 \pm 0,36$ & $1,69 \pm 0,46$ & $2,00 \pm 0,00$ \\
\hline 6 hónap & $1,88 \pm 0,32$ & $1,85 \pm 0,36$ & $1,87 \pm 0,34$ & $1,87 \pm 0,35$ & $1,83 \pm 0,38$ & $1,93 \pm 0,27$ & $1,85 \pm 0,36$ & $1,93 \pm 0,27$ \\
\hline
\end{tabular}

régi törekvés, hogy újabb eszközök bevonásával fokozzák a biofilm eltávolításának hatásfokát $[4,5,6]$.

A fogon megtapadó depozitumok eltávolítására, az ínyszél feletti területen már több mint 60 éve alkalmazzák a levegőabráziós tisztítást [9]. A hagyományos Nabikarbonát por alkalmazása a parodontitis következtében kialakuló tasakok kezelése során mind a keményszövetek [17, 18, 19, 20], mind a gingiva [21] komoly károsodásával járt együtt. Ahhoz, hogy az exponálódott cement és a tasakfal hámjának károsodását elkerüljék, más anyag után kellett nézni: mintegy 15 évvel ezelőtt a glycinport találták a feladatra alkalmasnak [10, 22, 23]. Saját vizsgálatunk során is bebizonyosodott, hogy a glycinport biztonságosan lehet alkalmazni, ahogy a $\mathrm{Ng} \mathrm{E}$ meta-analíziséből is kiderül [11].

A páciensek értékelése szerint a subgingivális airabrazív kezelés kevesebb diszkomfort érzést okoz, öszszehasonlítva akár kézi, akár ultrahangos gépi depurátorok, kürettkanalak alkalmazásával végzett terápiás beavatkozásokkal, amelyet a mi pácienseink beszámolói alapján is megerősíthetünk [12, 23, 24]. A gingiva károsodását vizsgálva Simon CJ és munkatársai szerint a gépi és kézi eszközökkel végzett subgingivális debrimentálás nagyobb mértékben okoz hámeróziót, mint a glycinporral végzett terápia [15, 25].

A klinikai és mikrobiológiai paraméterekkel kifejezhető hatás tekintetében megoszlanak a vélemények a subgingivális air-abrazív módszer hatásosságában. A legtöbb rendelkezésre álló adat a fenntartó terápia alatt, a fogkőmentes fogfelszínek kezeléséről állnak rendelkezésünkre. Az adatok összehasonlíthatóságát nehezíti, hogy a kiindulási szondázási mélységek és a vizsgált időtartamok nagyon heterogének. Három hónapos kontroll alapján Petersilka 3-5 mm-es kiindulási szondázási mélység mellett mind a klinikai, mind a mikrobiológiai paraméterek szerint jobbnak találta a glycinporral végzett kezelést a konvencionális mechanoterápiával összehasonlítva, míg Flemming és munkatársai hasonló időtartam alatt mind közepesen mély, mind mély tasakok esetében az életképes baktériumok számának csökkenésében talált előnyt az air-abrazív módszer esetében [22, 23, 26]. Rövid, 7 napos kontroll alapján Möene, 2 hónapos visszarendelési periódus szerint Wennström, míg hosszú, 12 hónapos időintervallumban Müller nem talált különbséget az air-abrazív és a hagyományos subgingivális debrimentálást összehasonlítva $4 \mathrm{~mm}$-es vagy mélyebb kiindulási tasakmélység értékek esetében [12, 14, 27]. Caygur és munkatársai az additív hatást vizsgálta rövid időintervallumban (7-1430 nap), közepesen mély tasakok (4-6 mm) terápiája során nem talált pozitív hatást a teszt csoportnál, ahol a hagyományos gyökérfelszín-simítást követően glycinporral levegőabráziós kezelést is végeztek [28]. Kargas $3 \mathrm{~mm}$-nél mélyebb kiindulási értékeknél, 3 és 6 hónapos kontrollidő alapján, rosszabb eredményeket kapott a glycinporral végzett kezelések esetében.

Kezeletlen parodontitis betegeknél végzett air-abrazív kezelésekről kevés közleményt találhatunk. Tsang és munkatársai 3 és 6 hónapos követési idővel a gyulladásos paraméterek javulását találták jobbnak az air-abrazív módszerrel kiegészített subgingivalis debrimentálás esetében, 3 hónappal a kezelést követően végzett vizsgálatok során. A többi paraméterben, illetve a hathónapos kontrollnál nem találtak kiegészítő hatást. Flemming és munkatársai 3 hónappal a beavatkozás után viszont effektívebb biofilm eltávolítást észleltek a glycinporral végzett kezeléseket követően [29, 30].

A fenti adatokhoz hasonlók az általunk mért paraméterek is: három hónappal a kezelést követően jobb értékeket kaptunk mind a gyulladást, mind a szövetpusztulást jellemző indexeknél, mint az egy hónapos ellenőrzéseknél. Valószínűleg a jobb biofilm-eltávolító képességet jelzi az is, hogy a nehezebben hozzáférhető területek esetében a glycinporral végzett kiegészítő kezelés jobb eredményt hozott, mint a konvencionális terápia. Valószínúleg a páciensek szájhigiéniája is befolyásolja a kezelés eredményét, ami a mi vizsgálatunk során az első hónap után rosszabb volt, mint a kezelés előtt, viszont újramotiválást követően a 3. hónapos ellenőrzés alatt jelentős javulást tapasztaltunk, ami utána ugyan romlott, de a hat hónapos értékek is jobbak voltak, mint a kiindulási és természetesen így az első hó- 
napos eredmények. Hasonló tapasztalatokról számolt be Flemming is [26].

$\mathrm{Ng}$ és munkatársai szisztematikus áttekintésükben megemlítik, hogy a kezelési protokollok még korántsem egységesek, különböző ideig tart egy felszín kezelése, eltérő nyomás, vízmennyiség értékek beállításával végzik a kezeléseket. Az egyes készülékek kialakításában is lényeges eltérések találhatók, az applikációs csúcs rugalmassága, a por kibocsátásának szöge is eltérő lehet [11]. In vitro titánfelszínen végzett kísérletében Tastepe azt találta, hogy a kezelés hatását elsősorban a fúvókánál jelentkező nyomás és vízmennyiség befolyásolja, valamint az, hogy milyen mélyre vezetjük a tasakba az applikációs csúcsot. A fúvóka tasakban történő mozgatásának iránya mindegy, viszont amennyiben álló helyzetben bocsátjuk ki a port, a mikroorganizmusok eltávolítása kevésbé lesz effektív [31].

A subgingivális air-abrazív terápia útkeresését jelzi az a tény is, hogy a glycinhez mérhető abrazivitású, de antibakteriális aktivitású, szubsztantív tulajdonsággal rendelkező port találjanak. A fogfelszínen kifejtett antimikrobiális hatás alapján felmerült az Erythritol [32], illetve kombinációban a klórhexidin-diglükonát alkalmazása [33, 34]. Az Erythritol kisebb részecskeméretü, mint a Glycin, ezáltal kisebb abrazív hatással bír, amely kedvezőbb a fogak szempontjából. Bár klinikai paraméterek alapján nem túnik hatásosabbnak sem a glycinporral végzett kezelésekkel, sem a konvencionális mechanoterápiával végzett beavatkozásokkal szemben a fenntartó terápia során, annak alternatívájaként mindenképpen szóba jöhet [24, 35]. In vitro kísérletben ígéretesnek tünik, hogy a klorhexidinnel kombinált Erythritolporral végzett ismételt kezelések után a biofilm újraképződés kisebb mértékú, mint a kézi eszközzel végzett gyökérfelszín-simítás után, míg az Erythritol önmagában hasonló módon gátolja a mikroorganizmusok megtapadását, mint az ultrahangos depurátorral végzett terápia, és mindkettő jobb ebből a szempontból, mint a kézi eszközök használatával tisztított fogfelszín [36].

A subgingivális terápia effektivitása ma még nehezen meghatározható a kevés számú és eltérő módszereket tartalmazó publikáció miatt. Saját vizsgálatunk eredményeit is fenntartással kell kezelni a kisebb elemszám miatt, illetve azért, mert jelenleg még nem állnak rendelkezésünkre mikrobiológiai, illetve más laboratóriumi paraméterek. Kíváncsian várjuk, hogy a további betegek bevonása, illetve a metagenomikus bakteriológiai analízis mennyire változtatja meg jelenlegi vizsgálatunk óvatos megállapításait, amelyek az air-abrazív subgingivális debrimentálás pozitív addítiív hatásáról szólnak, elsősorban a nehezen hozzáférhető helyeken, illetve hosszabb (3 hónapos) időtartam során.

\section{Anyagi támogatás:}

UNKP - Új Nemzeti Kiválósági Program ösztöndíjpályázat (UNKP-17-1-I-SZTE) segítségével bonyolítottuk le kutatásunkat.
A vizsgálat elvégzéséhez a Perio-Mate eszközt a NSK Europe Gmbh (Eschborn, Németország) bocsátotta rendelkezésünkre.

\section{Irodalom}

1. Papapanou PN, Sanz M, Buduneli N, Dietrich T, Feres M, Fine DH, et al: Periodontitis: Consensus report of workgroup 2 of the 2017 World Workshop on the Classification of Periodontal and PeriImplant Diseases and Conditions: Classification and case definitions for periodontitis. J Periodontol. 2018; 89: S1 73-82. https:// doi.org/10.1002/JPER.17-0721

2. Badersten A, Nilvéus R, Egelberg J: Effect of nonsurgical periodontal therapy. I. Moderately advanced periodontitis. J Clin Periodontol. 1981; 8: 57-72. https://doi.org/10.1111/j.1600-051X.1981. tb02024.X

3. Badersten A, Nilveus R, Egelberg J: Effect of nonsurgical periodontal therapy. II. Severely advanced periodontitis. J Clin Periodontol. 1984; 11: 63-76.

4. Graziani F, Karapetsa D, Alonso B, Herrera D: Nonsurgical and surgical treatment of periodontitis: how many options for one disease? Periodontol 2000. 2017; 75: 152-88.

5. Heitz-Mayfield LJA, LANG NP: Surgical and nonsurgical periodontal therapy. Learned and unlearned concepts. Periodontol 2000. 2013; 62: 218-231. https://doi.org/10.1111/prd.12008

6. Teles R, Teles F, Frias-Lopez J, Paster B, Haffajee A: Lessons learned and unlearned in periodontal microbiology. Periodontol 2000. 2013; 62: 95-162. https://doi.org/10.1111/prd.12010

7. Takasaki AA, Aoki A, Mizutani K, Schwarz F, Sculean A, Wang $\mathrm{C}-\mathrm{Y}$, et al: Application of antimicrobial photodynamic therapy in periodontal and peri-implant diseases. Periodontol 2000. 2009; 51: 109-140.

8. Petersilka GJ: Subgingival air-polishing in the treatment of periodontal biofilm infections. Periodontol 2000. 2011; 55: 124-142. https://doi.org/10.1111/j.1600-0757.2010.00342.x

9. BLACK RB: Technic for Nonmechanical Preparation of Cavities and Prophylaxis. J Am Dent Assoc. 1945; 32: 955-965. https:// doi.org/10.14219/jada.archive.1945.0129

10. Petersilka GJ, Bell M, Häberlein I, Mehl A, Hickel R, Flemmig TF: In vitro evaluation of novel low abrasive air polishing powders. J Clin Periodontol. 2003; 30: 9-13. https://doi.org/10.1034/j.1600 -051X.30.s5.5.X

11. Ng E, Byun R, Spahr A, Divnic-Resnik T: The efficacy of air polishing devices in supportive periodontal therapy: A systematic review and meta-analysis. Quintessence Int. 2018; 49: 453467.

12. Müller N, Moëne R, Cancela Ja, Mombelli A: Subgingival airpolishing with erythritol during periodontal maintenance: randomized clinical trial of twelve months. J Clin Periodontol. 2014; 41: 883-889. https://doi.org/10.1111/jcpe.12289

13. Kargas K, Tsalikis L, Sakellari D, Menexes G, Konstantinidis A: Pilot study on the clinical and microbiological effect of subgingival glycine powder air polishing using a cannula-like jet. Int $J$ Dent Hyg. 2015; 13: 161-169. https://doi.org/10.1111/idh.12104

14. Moëne R, Décalllet $F$, Andersen E, Mombelli A: Subgingival plaque removal using a new air-polishing device. J Periodontol. 2010; 81: 79-88. https://doi.org/10.1902/jop.2009.090394

15. Simon CJ, Munivenkatappa Lakshmaiah Venkatesh P, Chickanna R: Efficacy of glycine powder air polishing in comparison with sodium bicarbonate air polishing and ultrasonic scaling - a double-blind clinico-histopathologic study. Int J Dent Hyg. 2015; 13: 177-183. https://doi.org/10.1111/idh.12133

16. Quirynen M, Bollen CM, Vandekerckhove BN, Dekeyser C, PapaIOANNOU W, EYSSEN H: Full- vs. partial-mouth disinfection in the treatment of periodontal infections: short-term clinical and microbiological observations. J Dent Res. 1995; 74: 1459-1467. https://doi.org/10.1177/00220345950740080501 
17. Agger MS, Hörsted-Bindslev P, HovgaArd O: Abrasiveness of an air-powder polishing system on root surfaces in vitro. Quintessence Int. 2001; 32: 407-411.

18. Galloway SE, Pashley DH: Rate of removal of root structure by the use of the Prophy-Jet device. J Periodontol. 1987; 58: 464-469. https://doi.org/10.1902/jop.1987.58.7.464

19. Petersilka GJ, Bell M, Mehl A, Hickel R, Flemmig TF: Root defects following air polishing. J Clin Periodontol. 2003; 30: 165-170. https://doi.org/10.1034/j.1600-051X.2003.300204.x

20. AtKinson DR, Coвb CM, KILloy WJ: The effect of an air-powder abrasive system on in vitro root surfaces. J Periodontol. 1984; 55: 13-18. https://doi.org/10.1902/jop.1984.55.1.13

21. Kozlovsky A, Artzi Z, Nemcovsky CE, Hirshberg A: Effect of airpolishing devices on the gingiva: histologic study in the canine. J Clin Periodontol. 2005; 32: 329-334. https://doi.org/10.1111/j. 1600-051X.2005.00678.x

22. Petersilka GJ, Tunkel J, Barakos K, Heinecke A, Häberlein I, FLEMMIG TF: Subgingival plaque removal at interdental sites using a low-abrasive air polishing powder. J Periodontol. 2003; 74: 307-311. https://doi.org/10.1902/jop.2003.74.3.307

23. Petersilka GJ, Steinmann D, Häberlein I, Heinecke A, Flemmig TF: Subgingival plaque removal in buccal and lingual sites using a novel low abrasive air-polishing powder. J Clin Periodontol. 2003; 30: 328-333. https://doi.org/10.1034/j.1600-051X.2003. 00290.x

24. Hägi TT, Hofmänner $P$, Salvi Ge, Ramseier CA, Sculean A: Clinical outcomes following subgingival application of a novel erythritol powder by means of air polishing in supportive periodontal therapy: a randomized, controlled clinical study. Quintessence Int. 2013; 44: 753-761.

25. Peterilka G, Faggion CM, Stratmann U, Gerss J, Ehmke B, HaeBERLEIN I, et al: Effect of glycine powder air-polishing on the gingiva. J Clin Periodontol. 2008; 35: 324-332. https://doi.org/10.1111/ j.1600-051X.2007.01195.x

26. Flemmig TF, Arushanov D, Daubert D, Rothen M, Mueller G, Leroux BG: Randomized controlled trial assessing efficacy and safety of glycine powder air polishing in moderate-to-deep periodontal pockets. J Periodontol. 2012; 83: 444-452. https://doi.org/10.1902/ jop.2011.110367

27. Wennström JL, DahlÉn G, Ramberg P: Subgingival debridement of periodontal pockets by air polishing in comparison with ultrasonic instrumentation during maintenance therapy. J Clin Periodontol. 2011; 38 (9): 820-827.

28. Caygur A, Albaba Mr, Berberoglu A, Yilmaz HG: Efficacy of gly- cine powder air-polishing combined with scaling and root planing in the treatment of periodontitis and halitosis: A randomised clinical study. J Int Med Res. 2017; 45: 1168-1174. https://doi.org/10. 1177/0300060517705540

29. Flemmig TF, Hetzel M, Topoll H, Gerss J, Haeberlein I, Petersilka G: Subgingival debridement efficacy of glycine powder air polishing. J Periodontol. 2007; 78: 1002-1010. https://doi.org/10.1902/jop. 2007.060420

30. TSAng YC, Corbet EF, JIN LJ: Subgingival glycine powder airpolishing as an additional approach to nonsurgical periodontal therapy in subjects with untreated chronic periodontitis. $\mathrm{JPe}$ riodontal Res. 2018; 53: 440-445. https://doi.org/10.1111/jre. 12532

31. Tastepe CS, Lin X, Donnet M, Wismeijer D, Liu Y: Parameters That Improve Cleaning Efficiency of Subgingival Air Polishing on Titanium Implant Surfaces: An In Vitro Study. J Periodontol. 2017; 88: 407-414. https://doi.org/10.1902/jop.2016. 160270

32. Hashino E, Kubonima M, Alghamdi SA, Yamaguchi M, Yamamoto R, $\mathrm{CHO} \mathrm{H}$, et al: Erythritol alters microstructure and metabolomic profiles of biofilm composed of Streptococcus gordonii and Porphyromonas gingivalis. Mol Oral Microbiol. 2013; 28: 435-451. https://doi.org/10.1111/omi.12037

33. Khademi AA, Saleh M, KhabiRI M, Jahadi S: Stability of antibacterial activity of Chlorhexidine and Doxycycline in bovine root dentine. J Res Pharm Pract. 2014; 3: 19-22. https://doi.org/10.4103/ 2279-042X.132705

34. Zaugg LK, Zitzmann NU, Hauser-Gerspach I, Waltimo T, Weiger R, KRASTL G: Antimicrobial activity of short- and medium-term applications of polyhexamethylene biguanide, chlorhexidine digluconate and calcium hydroxide in infected immature bovine teeth in vitro. Dent Traumatol Off Publ Int Assoc Dent Traumatol. 2014; 30: 326-331. https://doi.org/10.1111/edt.12077

35. HäGı TT, Hofmänner $P$, Eıck S, Donnet M, Salvi GE, Sculean A, et al: The effects of erythritol air-polishing powder on microbiologic and clinical outcomes during supportive periodontal therapy: Six-month results of a randomized controlled clinical trial. Quintessence Int. 2015; 46: 31-41.

36. Hägi TT, Klemensberger S, Bereiter R, Nietzsche S, Cosgarea R FLuRY S, et al: A Biofilm Pocket Model to Evaluate Different NonSurgical Periodontal Treatment Modalities in Terms of Biofilm Removal and Reformation, Surface Alterations and Attachment of Periodontal Ligament Fibroblasts. PloS One. 2015; 10 (6): e0131056. https://doi.org/10.1371/journal.pone.0131056 


\section{KomLÓSI L, VÁLYI P}

\section{Efficacy of subgingival air-polishing in the non-surgical periodontal therapy of chronic periodontitis} Randomized controlled pilot study

Introduction: The causal treatment of plaque-related periodontal conditions is the removal of the biofilm that forms on tooth surfaces and contains pathogen microorganisms. The efficacy of non-surgical periodontal therapy is currently considered to reach $84 \%$, as the removal of deposits from subgingival area, thus the prevention of reinfections is extremely difficult. The novel air-polishing technology, which is able to reach the microscopic gaps, was adapted to improving a subgingival instrumentation. The purpose of this study was to evaluate the efficacy of air-polishing applied subgingivally through the measurement of clinical parameters.

Methods: In this randomized clinical trial 8 from 15 chronic periodontitis patients with a mean age of 51.4 years old were included. Subjects had to show a probing pocket depth (PPD) of $\geq 4 \mathrm{~mm}$ in case of at least 2 pockets per quadrant. The treatment was carried out in a split-mouth design: the full-mouth subgingival instrumentation was supplemented by additional glycine powder air-polishing by Perio-Mate instrument (NSK, Japan) on the test side. Parameters were recorded at baseline and 1, 3, and 6 month following treatment. The collected data were evaluated by non-parametric tests (Wilcoxon test within groups and Mann-Whitney $U$ test between groups) using Statistica 13.0 software.

Results: At 1 month no significant differences were found between the test and control sides $(p>0.01)$, nevertheless significant improvement was observed in all investigated parameters in both groups. Further significant improvement was found only in case of test sites at 3 months visit. Similar improvement was recorded at the test sides regardless difficult accessibility of individual sites (multi-rooted teeth, PPD $>5 \mathrm{~mm}$ ), but there were differences at the control sides: less improvement was observed at sites with difficulty in access to the root surface.

Conclusion: The additional effect of subgingival air-polishing as a supplementary treatment was observed at 3 months recall. However slight statistically differences supported the adjunctive effect, it seems to the subgingival air-abrasive methods improve the efficacy of mechanical instrumentation of root surface with difficult accessibility.

Keywords: chronic periodontitis, subgingival debridement, air-abrasive subgingival therapy 